\title{
Zinc status of cows as deduced from the liver zinc content
}

\author{
W. T. BINNERTS
}

Department of Animal Physiology, Wageningen Agricultural University, P.O. Box 9101, NL 6700 HB Wageningen, Netherlands

Received 2 August 1988; accepted 19 January 1989

\begin{abstract}
Zinc is an essential trace element, necessary for optimum production and wellbeing of man and animals. Reports on the occurrence of zinc in Dutch soils and feedstuffs are scarce; nevertheless some effects, or rather lack of effects, in livestock have been discussed. Here the zinc content of cow's liver is presented, resulting from two periods of sampling of slaughterhouse liver. A total of 333 samples obtained in autumn and early winter had an average zinc content in dry matter of $125 \pm 29 \mathrm{mg} \mathrm{kg}^{-1}$, with 32 outliers (contents of $212 \mathrm{mg} \mathrm{kg}^{-1}$ and higher). The distribution of the high outliers, along a line extending from NW to SE over the country, may be related to geophysical factors, but also to feeding practice. Some very low zinc contents could be found by subtraction of the residual active zinc that is part of enzymes, about $90 \mathrm{mg} \mathrm{kg}^{-1}$, and logarithmic transformation. Thus 29 low outliers could be traced, all with effective zinc storage below $10 \mathrm{mg} \mathrm{kg}^{-1}$. Hence in the total material, nearly $10 \%$ was gravely deficient, some $40 \%$ suboptimal, and $10 \%$ excessively rich in zinc. Liver zinc seems a good means of assessment of the liver status of cows, on a much shorter time basis than for typical storage elements like copper. As a means of finding interactions, the method proves less satisfactory, at least for zinc relative to copper and iron.
\end{abstract}

Keywords: zinc, liver, cows, copper, iron, anaemia

\section{Introduction}

Zinc is an essential trace element, participating in more than 200 enzymes and enzyme-related proteins (Hambidge, 1986) with direct action on the nuclear genome (Wu \& Wu, 1987; Castro, 1987). In deficiency and toxicity, the overall metabolism is endangered, and specially that of proteins and nucleic acids, with consequences for growth and production (Hambidge, 1986; Underwood, 1977), and also for reproduction (Apgar, 1985). The manifestations of zinc deficiency and toxicity are not much different among animals and man (Prasad, 1987).

Deficiency leads to loss of appetite and taste, disturbed keratogenesis and wound healing, impaired brain development and deficient immunity (Fenwick et al., 1985). Often, enzymic activity fails to release peptide hormones out of larger protein molecules (O’Dell, 1981; 1984) with subsequent deregulation of water metabo- 
lism, food utilization and some aspects of brain functioning. The focus of interest has often been on dermatological manifestations: so-called parakeratosis and associated lesions, which are of course prominent but need not be the most serious afflictions. In our laboratory, older experiments showed that serious production losses could occur before any skin lesion became apparent (1960, unpublished).

In toxicity, a poor and anaemic condition is present (Allen et al., 1983) often with increased iron storage (Ott et al., 1966). Involvement of the pancreas has been described (Allen et al., 1983) with marked contribution by kidney and abomasum. Among the farm animals, sheep and cattle belong to the less tolerant species (Underwood, 1977). In the Netherlands, no zinc toxicity had been reported, until recently in foals (Hoskam et al., 1982) and in calves (Wentink et al., 1985) given zinccontaminated roughage.

The purpose of this contribution is to obtain a systematic view of the status of dairy cows in the Netherlands. Earlier work has been incidental (Hartmans, 1965). From his feeding trials, it has become commonly accepted that zinc contents in dry matter of rations of $25 \mathrm{mg} \mathrm{kg}{ }^{-1}$ would be sufficient for maintenance and production of dairy cows. Such contents are practically always present in roughages and other feed. New assessments, however, seem to indicate that for safe and adequate provision 45 to $50 \mathrm{mg} \mathrm{kg}^{-1}$ should be present (Weigand \& Kirchgessner, 1982), if all interfering factors are taken into account. One of these factors is the reduced zinc absorption in diets with soybean products, so very usual in modern high-productivity feeding. Clinical zinc deficiency has already been reported from elsewhere with rations containing decidedly more than $25 \mathrm{mg} \mathrm{kg}^{-1}$ (Hambidge, 1986).

Parameters for judging the zinc status include concentration of zinc in plasma and unsaturated zinc-binding capacity (Pallauf \& Schwarz, 1984), ratio of copper to zinc in plasma, zinc in other blood fractions (Milne et al., 1985; Everett \& Apgar, 1984) and indirect measures like enzyme activities (Kirchgessner \& Roth, 1981), red cell uptake (Chesters \& Will, 1987), metallothionein in plasma (Heilmeyer et al., 1984; Bremner et al., 1985) and in liver (van Beek \& Baars, 1988). Here results for zinc in liver samples are presented. They are of higher value than many other methods of biochemical analysis; they are certainly better than blood analysis (Kirchgessner \& Roth, 1981) recently studied (Everett \& Apgar, 1984), and a good measure of the mobile zinc stores bound to metallothioneins at the site of the liver (Hamer, 1986),

\section{Materials and methods}

Liver was sampled from cows (at least $100 \mathrm{~g}$ cut from the pars caudatis) in slaughterhouses; the origin of the animals was traced and ascertained, so that information could be collated. There were two periods of survey in late autumn until early winter, at an interval of five years. In the first period (1977), 115 samples were taken in 6 slaughterhouses during about one month. In the second period (1982), 218 samples were obtained in 13 slaughterhouses during 1.5 month. The samples were packed in polyethylene foil and stored at $-20^{\circ} \mathrm{C}$, until analysis with duplicate subsamples. To estimate the content of zinc by flame atomic absorption spectrometry, $2 \mathrm{~g}$ was carefully dissected with glass knives, weighed and digested with nitric and 
sulfuric acid. The digestion liquids were diluted to exactly $50 \mathrm{ml}$ and the recorded absorption was compared with those of equally treated reference solutions of zinc sulphate. Not only zinc, but also iron, copper, and sometimes magnesium and molybdenum were determined. Recovery was tested. The results of analysis for copper have been discussed elsewhere (Binnerts, 1986). A provisional report of the zinc analysis has appeared (Binnerts \& Viets, 1986).

\section{Results}

The results of the investigation, averages, standard deviation and number of samples are listed for the different regions of the Netherlands in Table 1. The content of zinc during the second investigation (II) was higher than during the first (I), though this finding is obscured by the rather high standard deviations in some regions. After correction for the high outliers, the differences are no longer significant (except

Table 1. Content of zinc in dry matter of liver according to origin. ${ }^{1}$

\begin{tabular}{|c|c|c|c|c|}
\hline \multirow[t]{2}{*}{ Region } & \multicolumn{2}{|l|}{ Of all results } & \multicolumn{2}{|c|}{ Without high values ${ }^{2}$} \\
\hline & $\begin{array}{l}\text { mean } \pm S D \\
\left(\mathrm{mg} \mathrm{kg}^{-1}\right)\end{array}$ & $n^{3}$ & $\begin{array}{l}\text { mean } \pm S D \\
\left(\mathrm{mg} \mathrm{kg}^{-1}\right)\end{array}$ & $n$ \\
\hline Alkmaar I & $166.6 \pm 122.1$ & 18 & $106.8 \pm 17.7$ & 14 \\
\hline Alkmaar II & $177.8 \pm 110.4$ & 34 & $127.1 \pm 19.8$ & 26 \\
\hline Arnhem I & $119.6 \pm 26.5$ & 12 & $119.6 \pm 26.5$ & 12 \\
\hline Arnhem II & $140.8 \pm 66.5$ & 18 & $118.9 \pm 14.2$ & 16 \\
\hline Den Bosch I & $114.0 \pm 33.8$ & 14 & $105.2 \pm 7.0$ & 13 \\
\hline Den Bosch II & $150.8 \pm 55.9$ & 26 & $134.8 \pm 29.3$ & 23 \\
\hline Doetinchem I & $115.4 \pm 18.9$ & 16 & $115.4 \pm 18.9$ & 16 \\
\hline Zevenaar II & $134.7 \pm 27.4$ & 12 & $134.7 \pm 27.4$ & 12 \\
\hline Friesland I & $134.9 \pm 49.4$ & 18 & $124.8 \pm 25.6$ & 17 \\
\hline Friesland II & $166.9 \pm 72.7$ & 31 & $142.9 \pm 24.3$ & 27 \\
\hline Leyden II & $130.8 \pm 27.6$ & 20 & $130.8 \pm 27.6$ & 20 \\
\hline Meppel II & $133.4 \pm 12.9$ & 8 & $133.4 \pm 12.9$ & 8 \\
\hline The Peel I & $119.2 \pm 39.4$ & 16 & $110.2 \pm 16.8$ & 15 \\
\hline The Peel II & $152.3 \pm 55.7$ & 15 & $134.2 \pm 30.9$ & 13 \\
\hline Sittard I & $103.9 \pm 8.3$ & 16 & $103.9 \pm 8.3$ & 16 \\
\hline Sittard II & $143.7 \pm 48.8$ & 21 & $127.6 \pm 26.2$ & 18 \\
\hline Soest II & $192.1 \pm 141.1$ & 17 & $130.4 \pm 17.3$ & 14 \\
\hline Texel I & $111.0 \pm 20.0$ & 5 & $111.0 \pm 20.2$ & 5 \\
\hline Texel II & $117.1 \pm 19.7$ & 16 & $117.1 \pm 19.7$ & 16 \\
\hline All results I & $125 \pm 60$ & 115 & - & \\
\hline All result II & $153 \pm 76$ & 218 & - & \\
\hline All results $I+I I$ & - & & $125 \pm 29$ & 301 \\
\hline
\end{tabular}

\footnotetext{
${ }^{1}$ The individual results are given in: Groes, C. A. M. van der \& J. Klok, 1984. Not two livers are equal (in Dutch). Graduate thesis. Dept. of Animal Physiology, Wageningen Agricultural University.

${ }^{2}$ Excluded are all values of $212 \mathrm{mg} \mathrm{kg}^{-1}$ or more, i.e. those three times the standard deviation and more above the mean.

3 Number of samples.
} 


\section{W. T. BINNERTS}

for the regions Sittard and Den Bosch (Bois-le-Duc) where the first investigation provided too few samples). So for all practical purposes, the results can be aggregated as in one population of 301 samples with an average of $125 \pm 29 \mathrm{mg} \mathrm{kg}^{-1}$. This is in line with the value 130 for 'cattle liver' as given by the National Bureau of Standards, USA, and with published averages for cows (Doyle \& Spaulding, 1978); it is below the values ranging from 120 to over 200 for 'man and other animal species' (Underwood, 1977; Mertz, 1986), but higher than the average of a little above 100 $\mathrm{mg} \mathrm{kg}^{-1}$ for Norwegian slaughterhouse livers (Norheim \& Bjorland, 1981). The early results of Hart (1954) for a control group in a feeding experiment averaged $144 \mathrm{mg} \mathrm{kg}^{-1}(n=31)$. The most probable cause for the scatter would have been the different zinc status of the subjects.

Table 2. Livers with high contents of zinc in dry matter $\left(\mathrm{mg} \mathrm{kg}^{-1}\right)$ and their associated content of copper and iron.

\begin{tabular}{llrr}
\hline Region of origin & Zinc & Copper & Iron \\
North Holland I & 312 & 332 & - \\
& 339 & 335 & - \\
North Holland II & 345 & 11 & - \\
& 508 & 665 & - \\
& 212 & 8 & 773 \\
Friesland I & 219 & 93 & 426 \\
Friesland II & 240 & 718 & 202 \\
& 302 & 82 & 797 \\
& 318 & 676 & 162 \\
Gelder Valley II & 449 & 18 & 659 \\
& 483 & 42 & 587 \\
Meuse area I & 521 & 261 & 521 \\
& 306 & 60 & - \\
Meuse area II & 244 & 14 & 197 \\
& 271 & 97 & 228 \\
& 365 & 19 & 580 \\
& 435 & 276 & 394 \\
& 402 & 455 & 306 \\
& 481 & 677 & 285 \\
& 558 & 428 & 828 \\
& 229 & 28 & - \\
& 254 & 510 & - \\
& 216 & 70 & 194 \\
& 220 & 10 & 263 \\
& 234 & 656 & 282 \\
& 242 & 296 & 153 \\
& 282 & 341 & 413 \\
& 286 & 172 & 213 \\
& 258 & 236 & 323 \\
& 346 & 633 & 270 \\
& 275 & 818 & 124 \\
& 357 & 496 & 172 \\
\hline
\end{tabular}

\footnotetext{
${ }^{1}$ Not determined.
} 
The 32 outliers (with three times the standard deviation or higher above the average) probably relate to excesses of zinc supply. So Table 2 indicates the origin of liver rich in zinc, and states the associated contents of copper and iron. Except in North Holland and near the River Meuse (Maas), outliers are few. There is no clear relation to copper and iron contents, except for three to four cases with low copper and high iron, where induced copper deficiency associated with anaemia (Mills, 1981) may have been caused by the zinc excess.

The regional distribution of the 21 livers with contents of zinc higher than $250 \mathrm{mg}$ $\mathrm{kg}^{-1}$ (Fig. 1) is interesting. They are predominantly along a line from north-west to south-east through the centre of the country, which happens to coincide with a geological discontinuity. Volatile zinc of volcanic origin may have escaped to the surface. Zinc deposits are known along the same line, and some are being mined. Such deposits are not, however, known in the NW, where the discontinuity lies much deeper. Nevertheless, unexplicably high contents of zinc in soil and vegetation have been found there before (Hartmans, 1965).

Contents of magnesium and molybdenum were not excessive. The contents of copper with two clusters of values around 25 and $250 \mathrm{mg} \mathrm{kg}^{-1}$ have been discussed

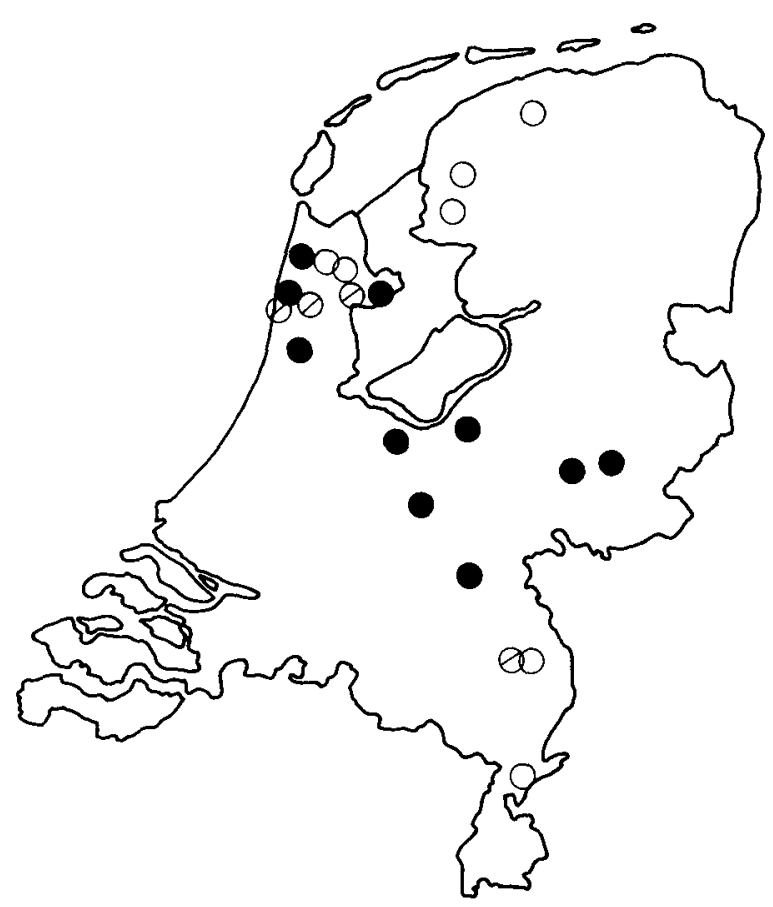

Fig. 1. Geographic distribution of livers high in zinc over the Netherlands. $\bigcirc$ simultaneously normal or low contents of copper; $\oslash$ idem, with high contents of iron; high contents of copper. 


\section{W. T. BINNERTS}

Table 3. Livers with extreme contents of iron $\left(\mathrm{mg} \mathrm{kg}^{-1}\right)$ and their associated contents of copper and zinc.

\begin{tabular}{lrrr}
\hline Region & Copper & Zinc & Iron \\
High iron contents & & & \\
Texel & 12 & 138 & 426 \\
& 22 & 130 & 397 \\
North-Holland & 8 & 212 & 733 \\
& 92 & 220 & 426 \\
& 82 & 302 & 797 \\
& 18 & 450 & 659 \\
South-Holland & 42 & 483 & 587 \\
& 12 & 186 & 1951 \\
Friesland & 302 & 164 & 409 \\
& 322 & 90 & 433 \\
& 276 & 435 & 394 \\
Den Bosch & 125 & 133 & 446 \\
Gelder Valley & 110 & 209 & 553 \\
The Peel & 428 & 558 & 828 \\
Sittard & 341 & 282 & 413 \\
Zevenaar & 10 & 186 & 435 \\
& 276 & 122 & 558 \\
Low iron contents & & & \\
Friesland & & & \\
Sittard & 540 & 112 & 125 \\
Arnhem & 10 & 162 & 110 \\
\hline
\end{tabular}

elsewhere (Binnerts, 1986), and the iron content averaged $215 \pm 61 \mathrm{mg} \mathrm{kg}^{-1}(n=$ 200 ), in the normal range of 110 to $400 \mathrm{mg} \mathrm{kg}^{-1}$.

In the 17 remaining livers rich in iron (range $394-1951 \mathrm{mg} \mathrm{kg}^{-1}$ ), a total of 8 to 9 were copper-deficient: 4 with less than $18 \mathrm{mg} \mathrm{kg}^{-1}$, in one liver $42 \mathrm{mg} \mathrm{kg}^{-1}$. Whereas our boundary value for copper was 25, studies at Florida, USA (McDowell et al., 1982) suggest up to $75 \mathrm{mg} \mathrm{kg}^{-1}$ as suspicious for deficiency. One liver was rich in both copper and zinc (428 and $558 \mathrm{mg} \mathrm{kg}^{-1}$, respectively).

Values for magnesium and molybdenum were normal, so that there was no liver damage nor grave toxicity.

\section{Discussion}

Although the regional averages after correction (Table 1) hardly differ, very high and very low values do occur.

High contents of zinc

The high values in Table 2 and Figure 1 are probably associated with special con- 
tents in soil and feed (Henkens, 1961; van Koetsveld \& Lehr, 1961, via Hartmans, 1965). In the areas where those authors found more than twice the highest normal values of $100 \mathrm{mg} \mathrm{kg}^{-1}$ in grass samples, some of the higher liver values are found in this investigation, as in North Holland, North Brabant (De Peel) and South Limburg (Sittard). However, these are local effects; for instance in South Limburg, where van Koetsveld \& Lehr (1961) report very high contents of zinc in grass, some of the lowest contents of zinc in liver were from Sittard in South Limburg during our first sampling. If a soil-plant-animal relationship exists, it is overruled, at least in the present material, by other factors. Such factors might be (1) fertilizer, (2), provision of zinc to cattle, (3) local feeding characteristics, and (4) the limited and temporary storage function of liver for zinc. These factors deserve close attention.

(1) As fertilizer, copper slag powder, known to contain more zinc than copper, has often been used. Also the enormous amounts of manure from livestock must contain much zinc. However on 45 farms, liver zinc was low, though liver copper was high.

(2) Zinc has been provided in two waves: around 1970 in combating the lethal strain A46 in the progeny of the steer Adema 21 (but long unnecessary), and before 1960 in regional advice based on the soil-plant-animal relationships. Although after-effects 'for up to six years' after dressing with zinc have been reported (Hambidge et al., 1986), these treatments seem too remote to have much impact now.

(3) Local use of large amounts of fodder beet, turnips, chicory roots and potatoes as feed in autumn and early in winter is a possible factor. In dry matter of these feeds, zinc contents ranged from 67 to $390 \mathrm{mg} \mathrm{kg}^{-1}$ (Hartmans, 1965). These contents are high compared to the normal 25 to $60 \mathrm{mg} \mathrm{kg}^{-1}$ for grasses, 20 to $30 \mathrm{mg} \mathrm{kg}^{-1}$ for cereal grain, and 50 to $70 \mathrm{mg} \mathrm{kg}{ }^{-1}$ for protein-rich supplements (Hambidge, 1986). Undoubtedly, some of the higher values in liver could be caused by such feeding in autumn. Another reason for a high zinc status in cows is grazing on river flats outside the winter dikes of the main rivers. In part of the present liver material (65 farms), however, a negative effect was found, not only on content of zinc but also of copper.

(4) For zinc, the studies are sensitive to the time of sampling, because of the dynamic nature of liver storage of zinc. Also the amount of zinc stored in the liver is not large relative to the daily intake. The sampling period of late autumn to early winter in this study should reveal the zinc status in autumn. Therefore it would be worthwhile to repeat sampling at other times of the year, in order to obtain a broader picture of zinc status.

For anaemia caused by conditioned copper deficiency, Table 3 may be helpful. High contents of iron in liver may result from inadequate serum copper and therefore inadequate mobilization of iron by ferroxidase activity. Besides copper deficiency (Mills, 1985), such high contents of iron are associated with infectious disease (Beisel et al., 1974; Gordunk et al., 1987) and with overloading. In only 6 (copper below $25 \mathrm{mg} \mathrm{kg}^{-1}$ ) and possible 7 (copper up to $42 \mathrm{mg} \mathrm{kg}^{-1}$ ) of the 17 livers are these high contents of iron associated with low contents of copper. And in three of the livers, zinc was sufficiently high to induce copper deficiency; no livers were low in zinc. 


\section{Low zinc contents}

The lower outliers (Table 4) were more difficult to trace, because of the large standard deviation. As generally for metals, the skew distribution is such that twice the standard deviation more than encompasses all lower results. To demonstrate deficiency, the data must be transformed. First, the zinc content of essential liver enzymes, $90 \mathrm{mg} \mathrm{kg}^{-1}$, is subtracted. In extreme deficiency, the liver will weigh considerably less than usual, but the zinc content will not be depressed much below $90 \mathrm{mg}$ $\mathrm{kg}^{-1}$. Kirchgessner et al. (1978) claim that, above that value (which could be approached by feeding rations extremely low in zinc, a linear relation exists with increasing zinc content of the rations. At higher zinc contents, the relation reached a plateau, because of the efficient homeostasis by the endogenous faecal excretion (Miller, 1969; Kirchgessner et al., 1976b; Weigand \& Kirchgessner, 1978). After

Table 4. Livers with low contents of zinc $\left(\mathrm{mg} \mathrm{kg}^{-1}\right)$ and their associated contents of copper and iron.

\begin{tabular}{|c|c|c|c|}
\hline Region of origin & Zinc & Copper $^{1}$ & Iron \\
\hline \multirow[t]{2}{*}{ Texel I } & 89 & & $-^{2}$ \\
\hline & 90 & & - \\
\hline \multirow[t]{4}{*}{ Texel II } & 97 & 204 & 203 \\
\hline & 97 & 239 & - \\
\hline & 96 & 65 & 249 \\
\hline & 99 & 75 & 204 \\
\hline \multirow[t]{5}{*}{ North Holland I } & 75 & & - \\
\hline & 88 & & - \\
\hline & 89 & & - \\
\hline & 90 & & - \\
\hline & 90 & & - \\
\hline \multirow[t]{2}{*}{ North Holland II } & 99 & 78 & 212 \\
\hline & 99 & 10 & 262 \\
\hline \multirow[t]{4}{*}{ Friesland I } & 98 & & - \\
\hline & 99 & & - \\
\hline & 99 & & - \\
\hline & 99 & & - \\
\hline Friesland II & 90 & 322 & 433 \\
\hline \multirow[t]{11}{*}{ Meuse area I } & 94 & & - \\
\hline & 96 & & - \\
\hline & 99 & & - \\
\hline & 96 & & - \\
\hline & 97 & & - \\
\hline & 92 & & - \\
\hline & 95 & & - \\
\hline & 95 & & - \\
\hline & 97 & & - \\
\hline & 98 & & - \\
\hline & 99 & & - \\
\hline
\end{tabular}

${ }^{1}$ Unfortunately the copper values are only available in a graph. They vary considerably and cannot reasonably be coupled with zinc, due to the small variation in zinc values.

${ }^{2}$ Not determined. 
subtraction of $90 \mathrm{mg} \mathrm{kg}^{-1}$, the zinc-deficient samples were found by logarithmic transformation: in the range 10 to $121 \mathrm{mg} \mathrm{kg}^{-1}$, the distribution of the log-transformed values was perfectly symmetrical around a median of 35 . The outliers were then those above 121 , as indicated above, and those below 10 , that means untransformed values below $100 \mathrm{mg} \mathrm{kg}^{-1}$. These data are given in Tables 2 and 4 .

The lower values in Table 4 came from the pasture areas along the coast, and from the Meuse region, at least during the first collection. No effects were found from management nor from small-scale variation in soil types. Also no general coupling with copper contents was present. A total of 6 of the 22 below 100 in the first study and 4 out of 20 below 110 in the second study were connected with copper contents lower than $25 \mathrm{mg} \mathrm{kg}^{-1}$; such animals probably had been pastured with grass low in minerals without receiving any concentrates. However, 4 out of 22 and 4 out of 20 of the livers low in zinc had simultaneous high copper contents of over $300 \mathrm{mg} \mathrm{kg}^{-1}$; in such cows, zinc deficiency must have been induced by an overload of copper.

\section{All zinc contents}

The regional distribution of zinc values is given in Table 5. The sum total of 29 deficient samples in Class $0-10$ amounts to nearly $10 \%$ of the material, whereas the other 132 samples below $30(40 \%)$ may be termed suboptimal, and the $32(10 \%)$ samples above 120 excessive to toxic. Judged by this criterion, the average zinc content of liver from Norwegian cows (Norheim \& Bjorland, 1981) just above Class 010 would be termed deficient. In other regions too, the zinc status of dairy cows seems unsatisfactory.

Table 5. Regional frequencies of corrected contents of zinc in liver. ${ }^{1}$

\begin{tabular}{llrrrr}
\hline Region & \multicolumn{3}{l}{ Class } & & \\
\cline { 2 - 6 } & $<0-10$ & $10-30$ & $30-60$ & $60-120$ & $>120$ \\
Texel & 6 & 8 & 5 & 2 & 0 \\
North Holland & 7 & 14 & 16 & 3 & 12 \\
South Holland & 0 & 8 & 9 & 3 & 0 \\
Friesland & 5 & 7 & 19 & 13 & 5 \\
Gelder Valley & 0 & 4 & 8 & 2 & 3 \\
Den Bosch & 3 & 21 & 6 & 6 & 4 \\
The Peel & 2 & 17 & 5 & 4 & 3 \\
Sittard & 6 & 19 & 5 & 4 & 3 \\
Doetinchem \& Zevenaar & 0 & 14 & 11 & 3 & 0 \\
Arnhem & 0 & 20 & 6 & 2 & 2 \\
Meppel & 0 & 1 & 6 & 1 & 0 \\
Total & 29 & 133 & 96 & 43 & 32 \\
\hline
\end{tabular}

${ }^{1}$ Expressed as $\mathrm{mg} \mathrm{kg}^{-1}$, and subsequently corrected by subtraction of $90 \mathrm{mg} \mathrm{kg}^{-1}$ for essential enzymes of liver (see Section 'Discussion'). 
Apart from the possibly insufficient or too abundant zinc supply, the effects of excessive amounts of other elements need to be considered. However, we found little evidence of such interaction, mainly because of the short period of survey for zinc compared to the other metals. The correlation coefficient of all liver zinc and copper contents is positive $(r=+0.31$ in the first, $r=+0.19$ in the second survey). This result may be biased by the large values, but it offers at least no proof, in the present material, for any negative interaction of copper and zinc absorption and metabolism.

Since the residence time of zinc in the liver is short, there is need for subsequent research in other seasons. Especially in spring, with more rapid growth and production, the zinc reserves could easily be exhausted. For such research, the present method is probably less suitable, since slaughterhouse samples in spring do not represent the whole population of cows.

\section{References}

Allen, J. G., H. G. Masters, R. L. Pelt, K. R. Mullins, R. D. Lewis, S. L. Skirrow \& J. Fry, 1983. Zine toxicity in ruminants. Journal of Comparative Pathology 93: 363-373.

Apgar, J., 1985. Zinc and reproduction. Annual Review of Nutrition 5: 43-68.

Beek, H. van \& A. J. Baars, 1988. Isolation and quantitation of cadmium-, zinc- and copper metallothioneins by high performance liquid chromatography-atomic absorption spectrometry. Journal of Chromatography 442: 345-352.

Beisel, W. R., R. S. Pekarek \& R. W. Wannemacher, 1974. The impact of infectious disease on traceelement metabolism of the host. In: W. G. Hoekstra et al. (Eds), Trace element metabolism in animals. TEMA-Symposium 2 (1974), p. 217-240. University Park Press, Baltimore.

Binnerts, W. T., 1986. The copper status of cattle in the Netherlands (in Dutch). Tijdschrifft voor Diergeneeskunde 111: 321-324.

Binnerts, W. T. \& T. C. Viets, 1986. Selenium metabolism, liver copper and zinc in cows. In: M. Anke et al. (Eds), 5. Internationales Spurenelementsymposium, p. 636-642. Universität Leipzig/Jena, DDR.

Bremner, I., R. K. Mehra \& M. Sato, 1985. Radioimmunoassay of metallothionein in the assessment of the trace metal status of animals. In: C. F. Mills et al. (Eds), Trace element metabolism in man and animals. TEMA-Symposium 5 (1984), p. 581-587. Commonwealth Agricultural Bureau, London.

Castro, C. E., 1987. Nutrient effects on DNA and chromatin structure. Annual Review of Nutrition 7 : 407-421.

Chesters, J. K. \& M. Will, 1987. The assessment of zinc status of an animal from the uptake of ${ }^{65} \mathrm{Zn}$ by the cells of whole blood in vitro. British Journal of Nutrition 39: 297-306.

Cunnane, S. C., 1982. Differential regulation of essential fatty acid metabolism by the prostaglandins: possible basis for the interaction of zine and copper in biological systems. Lipid Research 21: 73-90.

Davis, G. K., 1983. Microelement interactions of zinc, copper, and iron in mammalian species. In: O. A. Levander \& L. Cheng (Eds), Micronutrient interactions, vitamins, minerals and hazardous elements, p. 130-139. New York Academy of Sciences, New York, USA.

Doyle, J. J. \& J. E. Spaulding, 1978. Toxic and essential elements in meat. Journal of Animal Science 47: 411.

Everett, G. \& J. Apgar, 1984. Effect of low zinc intake on plasma and leucocyte zinc concentration in pregnant ewes. In: P. Schramel \& P. Brätter (Eds), Trace element analytical chemistry in medicine and biology, Vol. 3, p. 695-702. De Gruyter, Berlin/New York.

Fenwick, P., D. McDonald, P. J. Aggett, C. Huber \& D. Wakelin, 1985. The effect of zinc deficiency and repletion on the response of rats to infection with Stronggiloides ratti. In: C. F. Mills et al. (Eds), Trace element metabolism in man and animals. TEMA-Symposium 5 (1984), p. 220-222. Commonwealth Agricultural Bureau, London. 
Gordeuk, V. R., B. R. Bacon \& G. M. Brittenham, 1987. Iron overload: its causes and consequence. Annual Review of Nutrition 7: 485-508.

Hambidge, K. M., C. E. Casey \& N. F. Krebs, 1986. Zinc. In: W. Mertz (Ed.), Trace elements in human and animal nutrition, 5th ed., Vol. 2, p. 1-137. Academic Press, Orlando.

Hamer, D. H., 1986. Metallothionein. Annual Review of Biochemistry 55: 913-951.

Hartmans, J., 1965. An investigation to the zinc supply of the Netherlands cattle. Verslagen van Landbouwkundige Onderzockingen 664. Pudoc, Wageningen (in Dutch).

Heilmayer, H. E., P. Schramel, K. H. Summer, 1984. Determination of metallothionein as a tool for biological speciation of zinc. In: P. Brätter \& P. Schramel (Eds), Trace element analytical chemistry in medicine and biology, Vol. 3, p. 669-676. De Gruyter, Berlin/New York.

Hoskam, E. G., G. J. de Graaf, N. Noorman \& H. J. Over, 1982. Zinc poisoning in foals. Tijdschrijft voor Diergeneeskunde 107: 672-680 (in Dutch).

Kirchgessner, M. \& H.-P. Roth, 1981. Problems and possibilities in diagnosing zinc deficiency. In: J. McHowell et al. (Eds), Trace element metabolism in man and animal. TEMA-Symposium 4 (1981), p. 327-330. De Gruyter, Berlin.

Kirchgessner, M., H.-P. Roth \& E. Weigand, 1976. Biochemical changes in zine deficiency. In: A. S. Prasad (Ed.), Trace Elements in Human Health and Disease, Vol. 1, p. 189-225. Academic Press, New York.

McDowell, L. R., M. Kiatoko, J. E. Bertrand, H. L. Chapman, F. M. Pate, F. G. Martin \& J. H. Con$\mathrm{rad}, 1982$. Evaluating the nutritional status of beef cattle herds from four soil order regions of Florida. 2. Trace metals. Journal of Animal Science 55: 38-47.

Mills, C. F., 1981. Interactions between elements in tissues. Studies in animal models. Federation Proceedings 40: 2138-2142.

Mills, C. F., 1985. Dietary interactions involving the trace elements. Annual Review of Nutrition 5: 173193.

Milne, D. B., J. C. Wallwork \& N. V. C. Ralston, 1985. Analysis of zinc in blood cellular components as a means of assessment of zinc status. In: C. F. Mills et al. (Eds), Trace element metabolism in man and animal. TEMA-Symposium 5 (1984), p. 593-594. Commonwealth Agricultural Bureau, London.

Norheim, G. \& J. Bjorland, 1981. Zinc concentrations in pancreas and liver of cattle in Norway. Acta Veterinaria Scandinavica 22: 286-288.

O'Dell, B. L., 1981. Metabolic functions of zinc - a new look. In: J. McHowell et al. (Eds), Trace element metabolism in man and animal. TEMA-Symposium 4 (1981), p. 319-326. De Gruyter, Berlin.

Ott, E. A., W. H. Smith, R. B. Harrington, H. E. Parker \& W. M. Beeson, 1966. Zinc trials in ruminants. 4. Physiological changes in tissues of beef cattle. Journal of Animal Science 25: 432-438.

Pallauf, J. \& G. Schwarz, 1985. Experimental studies and biochemical criteria of zinc deficiency in the rabbit. In: C. F. Mills et al. (Eds), Trace element metabolism in man and animal. TEMA-Symposium 5 (1984), p. 587-590. Commonwealth Agricultural Bureau, London.

Prasad, A. S., 1985. Clinical manifestations of zinc deficiency. Annual Review of Nutrition 5: 341-361.

Snedecor, G. W. \& W. G. Cochran, 1976. Statistical Methods, 6th ed. The Iowa State University Press, Ames, Iowa, USA ( $329 \mathrm{pp}$ ).

Underwood, E. J., 1977. Trace Elements in Human and Animal Nutrition, 4th ed., Academic Press, New York.

Underwood, E. \& M. Somers, 1969. Zinc deficiency in ruminants. Australian Journal of Agricultural Research 20: 889-896.

Wentink, G. H., Th. J. Spierenburg, G. F. de Graaf \& A. C. A. van Exsel, 1985. A case of chronic zinc poisoning in calves fed zinc-contaminated roughage. Veterinary Quarterly 7: 153-157.

Wu, F. Y.-H. \& C.-H. Wu, 1987. Zinc in DNA replication and transcription. Annual Review of Nutrition 7: $251-272$. 